\title{
Analisis Penempatan Evolved Node B Area DKI Jakarta Dengan Menggunakan Algoritma Genetika Dan Evolutionary Programming
}

\author{
Riza Buddy Septyanto ${ }^{1}$, Endah Setyaningsih ${ }^{1}$ dan Fahraini Bacharuddin ${ }^{2}$
}

\begin{abstract}
Demand of higher data speed communication must be supported by good system and precise Evolved Node B allocation to give a good service quality. In the future especially Indonesia telecommunication network keep growing, data traffic with effective perfomance keep developed by mobile operator (service provider). Mobile telecomunication networking need cell planning with aim to meet cell coverage which is showed by number of base station, with minimal allocation but can meet the requirement of traffic capacity and coverage area. Chance to develope Long Term Evolution (LTE) Technology is at frequenies $1200 \mathrm{MHz}, 1800 \mathrm{MHz}, 2100 \mathrm{MHz}$ and 2300 MHz. eNode $B$ Allocation uses genetic algorithm and evolutionary programming. In Genetic Algorithm and evolutionary programming, searching technique is done by analyzing the size of the the population. Individual in one population is called by the term of chromosome. This chromosome is one of solution in the shape of symbol. In the beginning, population developed randomly, next population will be result of chromosomes evolution by iteration which is called by the term of generation. This eNode B allocation generates the best cell radius, observed by number of generations and eNode B allocation uses by using genetic algorithm and evolutionary programming which generate same cell radius.
\end{abstract}

Keywords: fitness, eNode B, genetic algorithm, evolutionary programming

\begin{abstract}
Abstrak: Kebutuhan akan komunikasi membutuhkan kecepatan data yang semakin tinggi sehingga harus didukung oleh sistem yang handal dan penempatan Evolved Node B yang tepat agar dapat memberikan kualitas layanan dengan baik. Dimasa depan khususnya di Indonesia jaringan telekomunikasi terus berkembang, lalu lintas data dengan performansi yang efektif terus dikembangkan oleh operator seluler (service provider). Jaringan komunikasi seluler membutuhkan perencanaan sel dengan tujuan untuk dapat memenuhi kebutuhan pencakupan sel yang ditunjukkan oleh jumlah base station, dengan penepatan seminimal mungkin tetapi dapat memenuhi kapasitas trafik dan coverage area yang dibutuhkan. Peluang untuk membangun teknologi Long Term Evolution (LTE) yaitu difrekuensi $1200 \mathrm{MHz}, 1800 \mathrm{MHz}, 2100$ MHz dan $2300 \mathrm{MHz}$. Penempatan eNode B menggunakan algoritma genetika dan evolutionary programming. Pada algoritma genetika dan evolutionary programming teknik pencarian dilakukan dengan menganalisa banyaknya populasi. Individu yang terdapat dalam satu populasi disebut istilah kromosom. Kromosom ini merupakan suatu solusi yang masih berbentuk simbol. Populasi awal dibangun secara acak, sedangkan populasi berikutnya merupakan hasil evolusi kromosom-kromosom melalui iterasi yang disebut dengan istilah generasi. Penempatan eNode B ini menghasilkan jari-jari sel yang terbaik dilihat dari banyaknya generasi yang ditentukan dan penempatan eNode B menggunakan algoritma genetika dan evolutionary programming menghasilkan nilai jari-jari sel yang sama.
\end{abstract}

Kata kunci: fitness, eNode B, algoritma genetika, evolutionary programming

\section{PENDAHULUAN}

$\mathrm{P}$ erkembangan jaringan telekomunikasi dewasa ini mengalami kemajuan yang sangat cepat. Berbagai macam fasilitas teknologi telekomunikasi terus dikembangkan agar user dapat melakukan komunikasi suara, data, grafik atau gambar. Hal ini ditandai dengan semakin banyaknya teknologi tanpa kabel yang digunakan oleh masyarakat. Salah satu teknologi tanpa kabel yang banyak dipakai masyarakat saat ini adalah telpon seluler GSM (Global System For Mobile communication). Menurut SM Research and Development of Service and Product, perkembangan telepon seluler GSM saat ini sudah mencapai 229,4 juta pengguna hingga tahun 2011[1]. Hal ini tentu memerlukan tersedianya infrastruktur jaringan yang mampu melayani pelanggan dengan kualitas yang baik dan memuaskan.

Kebutuhan akan komunikasi grafik atau gambar membutuhkan kecepatan data yang semakin tinggi sehingga harus didukung oleh sistem yang handal dan penempatan Evolved Node $B$ yang tepat agar dapat memberikan kualitas layanan dengan baik[2]. Dimasa depan khususnya di Indonesia jaringan telekomunikasi terus berkembang, lalu lintas data dengan performansi yang efektif dan efisien terus dikembangkan oleh operator seluler (service provider). Oleh karena itu perkembangan jaringan telekomunikasi bertujuan agar user dapat menikmati perkembangan tersebut untuk memenuhi kebutuhan informasi.

Jaringan komunikasi seluler membutuhkan perencanaan sel dengan tujuan untuk dapat memenuhi kebutuhan pencakupan sel yang ditunjukkan oleh jumlah base station, dimana diusahakan seminimal mungkin tetapi dapat memenuhi kapasitas trafik dan coverage area yang dibutuhkan. Peluang untuk membangun teknologi LTE yaitu difrekuensi $1200 \mathrm{MHz}, 1800 \mathrm{MHz}, 2100 \mathrm{MHz}$ dan $2300 \mathrm{MHz}$. Penerapan teknologi LTE membutuhkan biaya yang tidak sedikit dalam pembangunan infrastrukturnya. Operator harus melakukan perencanaan jumlah eNode B yang dibutuhkan untuk dapat menjangkau pelanggan. Penelitian ini bertujuan untuk mendapatkan gambaran berapa banyak eNode B yang dibutuhkan untuk penerapan teknologi LTE pada frekuensi $1200 \mathrm{MHz}$, $1800 \mathrm{MHz}, 2100 \mathrm{MHz}$ dan $2300 \mathrm{MHz}$ sehingga dapat menjadi pertimbangan oleh operator dalam menentukan pilihan untuk menggunakan frekuensi mana yang lebih efisien.

Algoritma genetika adalah teknik pencarian heuristik yang didasarkan pada gagasan evolusi seleksi alam dan genetik. Algoritma genetika banyak digunakan untuk memecahkan masalah dan pemodelan di bidang teknik, bisnis dan hiburan, termasuk didalamnya untuk proses optimasi[3]. Beberapa penelitian yang terkait dengan optimasi penentuan letak Evolved Node B dengan menggunakan Algoritma Genetika telah dilakukan, diantaranya

\footnotetext{
${ }^{1}$ Program Studi Teknik Elektro, Fakultas Teknik Universitas Tarumanagara

2 Jurusan Teknik Elektro Fakultas Teknik Universitas Mercu Buana Jakarta
} 
oleh Fabio Garzia dkk, dari penelitian tersebut didapatkan bahwa Algoritma Genetika memberikan hasil yang baik, dari segi coverage area yang dapat di-cover sebesar 90-95\% dan dari segi kapasitas pelanggan yang dapat dilayani sebanyak $98-99 \%$ [4].

Dalam tugas akhir ini permasalahan yang akan dibahas yaitu perencanaan penempatan Evolved Node $B$ seminimal mungkin di kota Jakarta tetapi masih menunjukkan hasil kerja yang efisien ditinjau pada frekuensi 1200 MHz, $1800 \mathrm{MHz}, 2100 \mathrm{MHz}$ dan $2300 \mathrm{Mhz}$ menggunakan Algoritma Genetika dan Algoritma Evolutionary Programming yang disimulasikan di software Matlab.

\section{Teknologi Long Term Evolution}

\section{KAJIAN PUSTAKA}

Long Term Evolution (LTE) adalah teknologi radio 4G yang masih dalam tahap pengembangan oleh Third Generation Partnership Project (3GPP) dengan kemampuan pengiriman data mencapai kecepatan $300 \mathrm{Mbit} / \mathrm{s}$ untuk downlink dan $75 \mathrm{Mbit} / \mathrm{s}$ untuk uplink. Bandwidth LTE beroperasi pada 1,4 MHz hingga $20 \mathrm{MHz}$. Kecepatan ini dapat dicapai dengan menggunakan Orthogonal Frequency Division Multiplexing (OFDM) pada downlink dan Single Carrier Frequency Division Multiplex (SC-FDMA) pada uplink, yang digabungkan dengan penggunaan MIMO. Teknologi LTE dirancang untuk menyediakan efisiensi spektrum yang lebih baik, peningkatan kapasitas radio, latency dan biaya operasional yang rendah bagi operator serta layanan pita lebar nirkabel bergerak kualitas tinggi untuk pengguna. Parameter LTE dapat dilihat pada Tabel 1.

- Tabel 1. Parameter LTE [5]

\begin{tabular}{|c|c|c|c|c|c|c|}
\hline Frequency range & \multicolumn{6}{|c|}{ UMTS FDD bands and TDD defined in 36.101 (v860) } \\
\hline $\begin{array}{l}\text { Channel bandwidth } \\
\text { (MHz) }\end{array}$ & 1,4 & 3 & 5 & 10 & 15 & 20 \\
\hline $\begin{array}{c}\text { Transmission } \\
\text { bandwidth NRS; }(1 \\
\text { resource block = } 180 \\
\text { KHz in } 1 \mathrm{~ms} \text { TTI })\end{array}$ & 6 & 15 & 25 & 50 & 75 & 100 \\
\hline \multirow{2}{*}{ Modulation schemes } & \multicolumn{6}{|c|}{ Downlink; QPSK, 16 QAM, 64 QAM } \\
\hline & \multicolumn{6}{|c|}{ Uplink; QPSK, 16 QAM (optional) } \\
\hline \multirow{2}{*}{ Multiple access } & \multicolumn{6}{|c|}{ Downlink; OFDMA } \\
\hline & \multicolumn{6}{|c|}{ Uplink; SC-FDMA } \\
\hline \multirow{2}{*}{$\begin{array}{l}\text { Multi-Antenna } \\
\text { Technology }\end{array}$} & \multicolumn{6}{|c|}{$\begin{array}{c}\text { Downlink ;TxAA, spatial multiplexing, CDD, max 4x4 } \\
\text { array }\end{array}$} \\
\hline & \multicolumn{6}{|c|}{ Uplink; Multi-user collaborative MIMO } \\
\hline \multirow[t]{2}{*}{ Peak data rate } & \multicolumn{6}{|c|}{$\begin{array}{c}\text { Downlink } 150 \text { Mbps (U E Category 4, 2x2 MIMO, } 20 \\
\text { MHz bandwidth) } \\
300 \text { Mbps (UE category 5, 4x4 MIMO } 20 \mathrm{MHz} \\
\text { bandwidth) }\end{array}$} \\
\hline & \multicolumn{6}{|c|}{ Uplink; 75 Mbps (20 MHz bandwidth) } \\
\hline
\end{tabular}

\section{Arsitektur Jaringan Long Term Evolution}

Arsitektur jaringan LTE dirancang untuk tujuan mendukung trafik paket switching dengan mobilitas tinggi, Quality of Service (QOS), dan latency yang kecil. Pendekatan paket switching ini memperbolehkan semua layanan termasuk layanan voice menggunakan koneksi paket. Oleh karena itu pada arsitektur jaringan LTE dirancang sesederhana mungkin, yaitu hanya terdiri dari dua node yaitu e Node B dan Mobility Management Entity/Gateway (MME/GW). Hal ini sangat berbeda dengan arsitektur teknologi GSM dan UMTS yang memiliki struktur lebih kompleks dengan adanya Radio Network Controller (RNC). Beberapa keuntungan yang dapat diperoleh dengan hanya adanya single node pada jaringan akses adalah pengurangan latency dan distribusi beban proses RNC untuk beberapa e Node B. Bentuk arsitektur LTE dapat dilihat pada Gambar 1. 


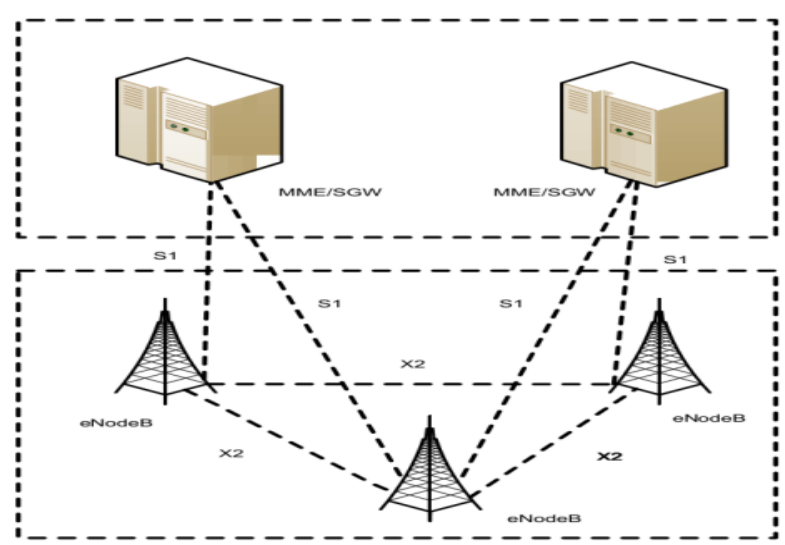

- Gambar 1 Bentuk Arsitektur LTE [5]

\section{Long Term Evolution Air Interface}

Pada sisi air interface transmisi dalam arah downlink dan uplink berbeda. Pada arah downlink teknik akses yang digunakan adalah Orthogonal Frequency Division Modulation Access (OFDMA) dan pada arah uplink teknik akses yang digunakan adalah Single Carrier Frequency Division Multiple Access (SC-FDMA). OFDMA adalah variasi dari Orthogonal Frequency Division Modulation (OFDM). Pada teknik OFDM subcarrier adalah orthogonal sehingga akan menghemat spektrum frekuensi dan setiap subcarrier tidak akan saling mempengaruhi. MIMO (Multiple Input Multiple Output ) digunakan untuk meningkatkan data rate pada teknologi seluler untuk menyediakan peningkatan tingkat efesiensi, MIMO menggunkan multiple antena pada receiver dan transmitter untuk memanfaatkan multi-path effect yang selalu ada untuk mentrasmisikan data tambahan. Akan tetapi salah satu kelemahan teknik akses ini adalah tingginya Peak Average Power Ratio (PAPR) yang dibutuhkan. Tingginya PAPR dalam OFDM membuat 3GPP melihat skema teknik akses yang berbeda pada arah uplink karena akan sangat mempengaruhi konsumsi daya sehingga pada arah uplink LTE menggunakan teknik SC-FDMA. SCFDMA dipilih karena teknik ini mengkombinasikan keunggulan PAPR yang rendah dengan daya tahan terhadap gangguan lintasan jamak dan alokasi frekuensi yang fleksibel dari OFDMA.

\section{PERENCANAAN SEL LONG TERM EVOLUTION}

\section{Perencanaan Berdasarkan Kapasitas}

Berikut ini tahapan dalam perencanaan kapasitas sel LTE :

1. Menentukan lokasi dan potensi wilayah serta permintaan pelanggan yang akan dicakup oleh LTE.

2. Menentukan jumlah pelanggan layanan Long Term Evolution

Jaringan yang dibangun digunakan dalam kurun waktu yang lama. Dalam periode tertentu, untuk mengantisipasi pertumbuhan pelanggan yang semakin meningkat maka diperlukan estimasi pertumbuhan pelanggan dengan persamaan sebagai berikut :

$$
\mathrm{Un}=\mathrm{Uo}(1+\mathrm{fp})^{\mathrm{n}} \text {. }
$$

\section{Keterangan :}

Un = Jumlah total pengguna setelah tahun ke-n

Uo = Jumlah pengguna saat perencanaan

$\mathrm{fp}=$ Faktor pertumbuhan

$\mathrm{n} \quad=$ Jumlah tahun prediksi

3. Menentukan kapasitas trafik LTE berdasarkan Offered Bit Quantity (OBQ)

Pada tahap memperkirakan besar kebutuhan suatu trafik merupakan hal yang penting dalam jaringan radio. Di dapatnya besar kebutuhan suatu trafik selanjutnya memudahkan dalam perencanaan kapasitas suatu jaringan optimal yang nantinya akan dibangun, selain itu dapat diketahui juga seberapa banyak perangkat eNode B yang diperlukan untuk memenuhi kebutuhan trafik pada suatu daerah. Perhitungan total kebutuhan trafik yang diperlukan dapat dihitung menggunakan metode Offered Bit Quantity (OBQ). OBQ merupakan total bit throughput per $\mathrm{km}^{2}$ pada jam sibuk. Dimana persamaan perhitungan OBQ adalah sebagai berikut : $\mathrm{OBQ}=\sigma \cdot p \cdot d \cdot \mathrm{BHCA} \cdot \mathrm{BW}$. ..(2.2)[5]

Keterangan :

$\sigma \quad=$ kepadatan pelanggan potensial dalam suatu daerah $\left(\mathrm{user} / \mathrm{km}^{2}\right)$

$\mathrm{p} \quad=$ penetrasi pengguna tiap layanan

$\mathrm{d}=$ durasi atau lama panggilan efektif (s)

$\mathrm{BHCA}=$ Busy Hour Call Attempt (call/s)

BW $=$ Bandwidth tiap layanan (Kbps) 
4. Pendimensian sel

Pada tahap pendimensian suatu sel ini bertujuan untuk menentukan berapa

jumlah sel yang dibutuhkan dalam suatu daerah untuk satu frekuensi carrier. Pendimensian sel meliputi :

a. Luas Cakupan Satu Sel

Untuk menentukan luas cakupan satu sel dapat di hitung menggunakan persamaan :

$$
L=\frac{K S e l}{O B Q}
$$

Keterangan :

$\mathrm{L} \quad=$ luas cakupan satu sel $\left(\mathrm{km}^{2}\right)$

KSel = kapasitas informasi tiap sel

$\mathrm{OBQ} \quad=$ Offered Bit Quantity

b. Penentuan Jumlah Sel

Untuk menentukan berapa jumlah sel yang dibutuhkan untuk memberi cakupan yang optimal pada suatu wilayah sesuai kebutuhan trafik pada wilayah tersebut dapat dihitung menggunakan persamaan :

$$
J=\frac{L W}{L}
$$

Keterangan :

$\mathrm{J}=$ jumlah sel

$\mathrm{LW}=$ luas area atau luas wilayah $\left(\mathrm{km}^{2}\right)$

$\mathrm{L}=$ luas cakupan satu sel

c. Penentuan Radius Sel

Untuk menentukan radius yang dihasilkan dari setiap sel dapat dihitung

menggunakan persamaan :

$$
\text { Rsel }=\sqrt{\frac{L}{2,59}}
$$

Keterangan :

Rsel = radius sel

$\mathrm{L} \quad=$ luas cakupan satu sel

\section{Perencanaan Berdasarkan Coverage}

Berikut ini tahapan dalam perencanaan coverage sel LTE

1. Perhitungan Link Budget

Link budget merupakan sebuah cara untuk menghitung mengenai semua parameter dalam transmisi sinyal, mulai dari gain dan losses dari Tx sampai Rx melalui media transmisi. Link budget merupakan parameter dalam merencanakan suatu jaringan yang menggunakan media transmisi berbagai macam. Link budget dihitung berdasarkan jarak antara transmitter $(\mathrm{Tx})$ dan receiver $(\mathrm{Rx})$. Link budget dihitung karena adanya penghalang antara Tx dan Rx misal gedung atau pepohonan.

2. Path Loss Model

Path Loss adalah loss yang terjadi ketika data/sinyal melewati media udara dari antena ke penerima dalam jarak tertentu. Path loss mengakibatkan penurunan level daya pada sisi penerima yang secara umum diakibatkan dengan adanya difraksi, refleksi, dan scattering. Selain itu path loss juga dipengaruhi oleh kondisi lingkungan, kontur wilayah, jarak antara transmitter dan receiver, serta tinggi dan penempatan antena.

- Model Propagasi Okumura Hata

Model propagasi Okumura Hata adalah empiris dari rugi-rugi propagasi yang telah diajukan. Rugi-rugi propagasi rata-rata didaerah urban dinyatakan dengan persamaan :

$$
\begin{aligned}
& \mathrm{L}_{\text {Prop City }}=69,55+26,16 \log \mathrm{f}-13,83 \log \mathrm{h}_{\mathrm{tx}}-\mathrm{a}\left(\mathrm{H}_{\mathrm{rx}}\right)+\left(44,9-6,55 \log \mathrm{h}_{\mathrm{tx}}\right) \log
\end{aligned}
$$

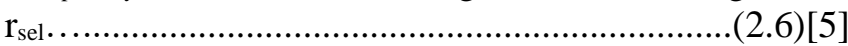

Keterangan :

$\mathrm{L}=$ Maximum allowable pathloss $(\mathrm{dB})$

$\mathrm{f} \quad=$ Frekuensi $(\mathrm{MHz})$

$\mathrm{h}_{\mathrm{tx}} \quad=$ Tinggi antena $\mathrm{tx}(\mathrm{m})$

$\mathrm{a}\left(\mathrm{H}_{\mathrm{rx}}\right) \quad=$ Penguatan path loss $(\mathrm{dB})$

$\mathrm{r}_{\mathrm{sel}} \quad=$ Jari-jari sel $(\mathrm{Km})$

3. Penentuan jumlah eNode B 
Penentuan jumlah eNode B dapat dilakukan setelah mengetahui radius luas cakupan dari masing - masing sel. Penentuan jumlah e Node B dapat dilakukan dengan persamaan :

$$
\Sigma \mathrm{eNB}=\frac{\text { luas wilayah yang akan dibangun jaringan }}{\text { luas cakupan sel }} \ldots \ldots \ldots \ldots \ldots(2.7)[5]
$$

\section{Algoritma Genetika}

Algoritma Genetika adalah algoritma pencarian heuristik yang didasarkan atas mekanisme evolusi biologis. Keberagaman pada evolusi biologis adalah variasi dari kromosom antar individu organisme. Variasi kromosom ini akan mempengaruhi laju reproduksi dan tingkat kemampuan organisme untuk tetap hidup. pada dasarnya ada 4 kondisi yang sangat mempengaruhi proses evaluasi yaitu :

1. kemampuan organisme untuk melakukan reproduksi

2. keberadaan populasi organisme yang bisa melakukan reproduksi

3. keberagaman organisme dalam suatu populasi

4. perbedaan kemampuan untuk survive

Individu yang lebih kuat (fit) akan memiliki tingkat survival dan tingkat reproduksi yang lebih tinggi jika dibandingkan dengan individu yang kurang fit. Pada kurun waktu tertentu (sering dikenal dengan istilah generasi), populasi secara keseluruhan akan lebih banyak memuat organisme yang fit.

Algoritma Genetika pertama kali dikembangkan oleh John Holland dari universitas Michigan. John Holland mengatakan bahwa setiap masalah yang berbentuk adaptasi (alami maupun buatan) dapat diformulasikan dalam terminologi genetika. Algoritma genetika adalah simulasi dari proses evolusi Darwin dan operasi genetika atas kromosom.

\section{Struktur Umum Algoritma Genetika}

Pada algoritma teknik pencarian dilakukan sekaligus atas sejumlah solusi yang mungkin yang dikenal dengan populasi. Individu yang terdapat dalam satu populasi disebut istilah kromosom. Kromosom ini merupakan suatu solusi yang masih berbentuk simbol. Populasi awal dibangun secara acak, sedangkan populasi berikutnya merupakan hasil evolusi kromosom-kromosom melalui iterasi yang disebut dengan istilah generasi. Pada setiap generasi, kromosom akan melalui proses evaluasi dengan menggunakan alat ukur yang disebut dengan fungsi fitness.

Nilai fitness dari suatu kromosom akan menunjukkan kualitas kromosom dalam populasi tersebut. Generasi berikut dikenal dengan istilah anak (offspring) terbentuk dari gabungan 2 kromosom generasi sekarang yang bertindak sebagai induk (parent) dengan menggunakan operator penyilangan (crossover). Selain operator penyilangan, suatu kromosom juga dapat dimodifikasi dengan menggunakan operator mutasi.

Populasi generasi yang baru dibentuk dengan cara menyeleksi nilai fitness dari kromosom induk (parent) dan nilai fitness dari kromosom anak (offspring), serta menolak kromosom-kromosom yang lainnya sehingga ukuran populasi (jumlah kromosom dalam suatu populasi) konstan. Setelah melalui beberapa generasi, maka algoritma ini akan konvergen ke kromosom terbaik.

\section{Komponen-komponen Utama Algoritma Genetika}

Ada 6 komponen utama dalam algoritma genetika, yaitu :

1. Teknik Penyandian

Teknik penyandian disini meliputi penyadian gen dari kromosom. Gen merupakan bagian dari kromosom. Satu gen biasanya akan mewakili satu variabel. Gen dapat dipresentasikan dalam bentuk: string bit, pohon, array bilangan real, daftar aturan, elemen permutasi, elemen program, atau representasi lainnya yang dapat diimplementasikan untuk operator genetika.

2. Prosedur Inisialisasi

Ukuran populasi tergantung pada masalah yang akan dipecahkan dan jenis operator genetika yang akan diimplementasikan. Setelah ukuran populasi ditentukan, kemudian harus inisialisai terhadap kromosom yang terdapat pada populasi tersebut. Inisialisasi kromosom dilakukan secara acak, namun demikian harus tetap memperhatikan domain solusi dan kendala permasalahan yang ada.

3. Fungsi Evaluasi

Ada 2 hal yang harus dilakukan dalam melakukan evaluasi kromosom, yaitu: evaluasi fungsi objektif (fungsi tujuan) dan konversi fungsi objektif kedalam fungsi fitness. Secara umum, fungsi fitness diturunkan dari fungsi objektif dengan nilai tidak negatif. Apabila ternyata fungsi objektif memiliki nilai negatif, maka perlu ditambahkan suatu konstanta $\mathrm{C}$ agar nilai fitness yang terbentuk menjadi tidak negatif.

4. Seleksi

Seleksi ini bertujuan untuk memberikan kesempatan reproduksi yang lebih besar bagi anggota populasi yang paling fit.

5. Operator Genetika 
Ada 3 operator genetika, yaitu:
a. Reproduksi
b. Operator untuk melakukan rekombinasi, yang terdiri dari: rekombinasi bernilai biner (crossover).
c. Mutasi. mutasi bernilai biner

6. Penentuan parameter

Yang disebut parameter yaitu parameter kontrol algoritma genetika, yaitu: ukuran populasi (popsize), peluang crossover $\left(\mathrm{P}_{\mathrm{c}}\right)$, dan peluang mutasi $\left(\mathrm{P}_{\mathrm{m}}\right)$. Nilai parameter ini ditentukan juga berdasarkan permasalahan yang akan dipecahkan.

\section{Operator Algoritma Genetika \\ Reproduksi}

Reproduksi merupakan sebuah string individu disalin kembali menjadi individu baru yang akan dipersiapkan menjadi orang tua. Kegunaan dari penyeleksian orang tua dalam algoritma genetika yaitu agar mendapatkan anggota populasi yang terbaik.

\section{Crossover}

Pada crossover akan dipilih secara acak dua individu dan tempat pertukaran, dimana kromosom yang ditandai diantara kedua tempat pertukaran akan bertukar tempat satu sama lain. Proses crossover akan membangkitkan offspring baru dengan mengganti sebagian informasi dari parents (orang tua atau induk). Tujuan dari proses crossover adalah untuk menambahkan keanekaragaman individu dalam populasi dengan mengawinkan individu-individu pada populasi sehingga menghasilkan keturunan berupa individu-individu baru untuk ditempatkan pada populasi selanjutnya. Ada beberapa tipe crossover, antara lain :

\section{One Cut Point Crossover}

Pada tipe ini, akan dibuat satu titik crossover dimana individu yang dihasilkan akan diambil dari bilangan biner parent pertama dari awal sampai titik crossover dan sisanya dari parent kedua. Algoritmanya adalah :

a. Memilih site secara random dari parent pertama.

$b$. Isi disebelah kanan site pada parent pertama ditukar dengan parent kedua untuk menghasilkan offspring. Gambar 2 menunjukkan contoh single point crossover.

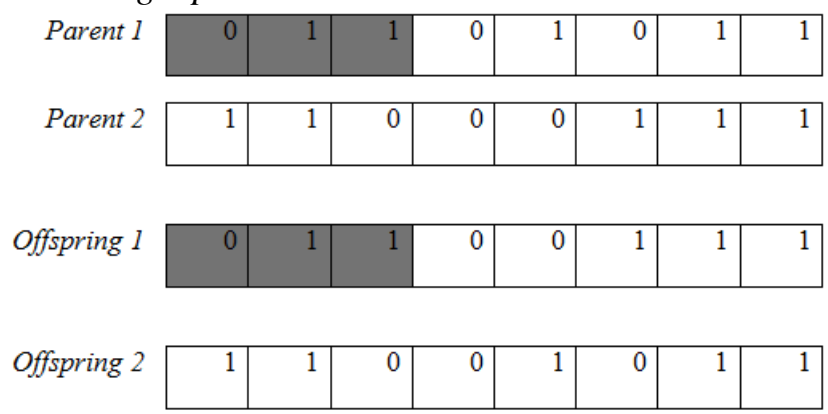

- Gambar 2. Contoh Single Point Crossover

2. Order Based Crossover

Pada tipe ini, offspring yang dihasilkan hanya satu hasil dari kombinasi kedua parent. Contoh order based crossover dapat dilihat pada Gambar 3.

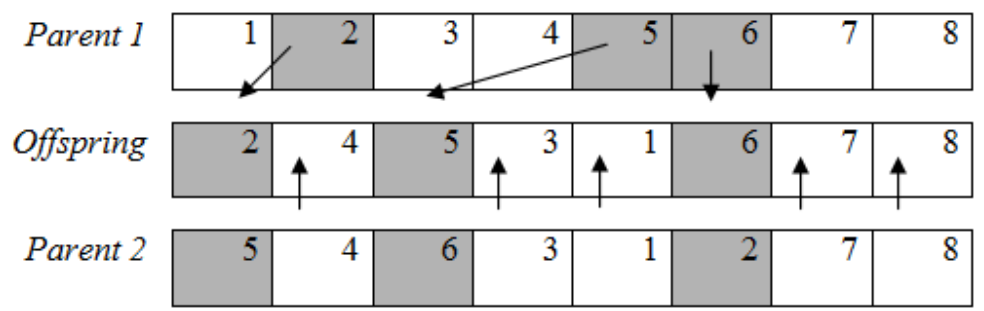

- Gambar 3. Contoh Order Based Crossover

\section{Mutasi}

Mutasi menciptakan individu baru dengan melakukan modifikasi satu atau lebih gen dalam individu yang sama. Mutasi berfungsi untuk menggantikan gen yang hilang dari populasi selama proses seleksi serta menyediakan gen yang tidak ada dalam populasi awal, sehingga mutasi akan meningkatkan variasi populasi. Shif mutation lihat Gambar 4 dilakukan dengan cara :

- Menentukan dua site secara random. 
- Site pertama ditempatkan ke site kedua, untuk selanjutnya digeser ke kiri seperti terlihat pada gambar berikut.

\begin{tabular}{|l|l|l|l|l|l|l|l|l|}
\hline Parent & 1 & 2 & 3 & 4 & 5 & 6 & 7 & 8 \\
\hline Offspring & 1 & 2 & 7 & 4 & 5 & 6 & 3 & 8 \\
\hline
\end{tabular}

\section{EVOLUTIONARY PROGRAMMING}

\section{Individual}

Dalam evolutionary programming, individual adalah kandidat solusi untuk permasalahan yang ingin dicari solusinya. Karakteristik suatu individual diwakili oleh kromosom atau genome, digambarkan dengan suatu pita gen, dimana setiap gen merupakan bagian kecil dari kandidat solusi. Kromosom terdiri dari dua kelas, yaitu genotype dan phenotype. Individual membentuk populasi. Individual merepresentasikan kemungkinan solusi untuk masalah yang ditangani, dan biasanya juga disertakan informasi lainnya seperti parameter strategi (strategy parameter) dan kesesuaian individual (individual's fitness).

\section{Populasi}

Populasi memiliki peran sebagai representasi dari segala kemungkinan solusi. Populasi merupakan kumpulan individual atau populasi merupakan multiset dari genotypes. Genotypes adalah sejumlah karakter yang diwariskan yang tetap terkandung dalam seluruh proses reproduksi populasi. Jika ukuran populasi kecil, agar tetap mencakup sebagian besar dari search space, maka keragaman populasi (population diversity) harus diperhatikan. Jika diperlukan, dalam evolutionary programming populasi bisa memiliki struktur spasial tambahan, yaitu dengan ukuran jarak atau hubungan antar tetangga (neighbourhood relations). Untuk menjaga keragaman populasi, operator mutasi sering disarankan menjadi solusi.

Evolutionary programming memiliki kemampuan optimisasi yang powerful meski dengan ukuran populasi yang relatif kecil. Dalam kasus populasi kecil, evolutionary programming dapat digunakan untuk mengeksplorasi search space yang lebih besar, yaitu dengan meningkatkan tingkat mutasi (mutation rate).

\section{Fitness Function}

Fitness function merupakan komponen yang penting dalam suatu evolutionary programming. Tujuan Fitness function adalah untuk memetakan representasi kromosom ke suatu nilai skalar. Fitness function digunakan untuk mengevaluasi seberapa baik suatu individual dapat digunakan dalam memecahkan masalah yang dikehendaki, fitness function juga berperan untuk menentukan individual mana yang akan bereproduksi dan sebagian materi genetiknya (yaitu bagian dari kandidat solusinya) akan diwariskan kepada penerusnya/generasi berikutnya. Semakin besar kesesuaian (fitness) suatu individual, semakin tinggi peluang individual tersebut terpilih untuk operasi reproduksi, kawin silang (crossover), dan mutasi. Idealnya, suatu fitness function bisa mengukur kualitas suatu individu (candidate solution) seakurat mungkin, namun desain dari fitness function juga akan memiliki batasan tentang processing power, latar belakang pengetahuan, dan persyaratan yang ditentukan user.

\section{Metode Seleksi}

Metode seleksi yang dimaksud untuk mencakup mekanisme seleksi induk (parents) dan mekanisme seleksi survivor. Peran pemilihan parents dalam evolutionary programming adalah untuk membedakan antara individual berdasarkan kualitasnya dan memberi kesempatan individual yang lebih baik untuk menjadi parents bagi generasi berikutnya. Semakin baik tingkat kesesuaian (dalam ukuran kualitas) suatu individual, semakin tinggi peluang individual tersebut untuk terpilih.

Seperti pemilihan parents, pemilihan survivor juga berperan berperan untuk membedakan individual berdasarkan kualitasnya, perbedaannya hanya pada proses keduanya dilakukan pada tahap yang berbeda. Pemilihan survivor dilakukan setelah proses penciptaan offspring dari parents terpilih.

\section{Kerangka Berpikir}

Penempatan eNode B dalam jaringan Long Term Evolution (LTE) tidak dapat dipisahkan satu sama lain. Saat ini banyak provider pemberi jasa layanan jaringan telekomunikasi yang sedang mengembangkan LTE di seluruh wilayah Indonesia khususnya dalam penempatan eNode B. Penempatan eNode B yang tepat akan memberikan kemudahan untuk pelanggan dalam mengakses data secara mobile. Peningkatan jumlah pelanggan akan memberikan pengaruh pada kualitas data yang akan diterima. Agar kualitas layanan yang diterima masih terjaga, operator provider perlu menambah jumlah eNode B untuk penempatan ulang. Pengoptimalan dalam penempatan eNode B digunakan Algoritma Genetika dan Evolutionary Programming untuk mendapatkan nilai fitness yang terbaik, agar dapat mencangkup wilayah DKI Jakarta dengan penempatan eNode B seminimal 
mungkin tetapi masih menunjukkan hasil kerja yang efisisen ditinjau dari frekuensi $1200 \mathrm{MHz}, 1800 \mathrm{MHz}, 2100$ MHz dan $2300 \mathrm{MHz}$, sehingga mendapat gambaran berapa banyak jumlah eNode B yang dibutuhkan untuk penerapan teknologi LTE.

\section{Hipotesis Penelitian}

1. Algoritma Genetika lebih baik untuk menentukan demand trafik dan daya jangkauan di kota Jakarta.

2. Algoritma Genetika dalam menentukan daerah yang tercover lebih baik jika dibandingkan dengan Evolutionary Programming.

3. Hasil penempatan jumlah eNode B dengan menggunakan frekuensi $2300 \mathrm{MHz}$ lebih efisien jika dibandingkan dengan frekuensi $1200 \mathrm{MHz}, 1800 \mathrm{MHz}$ dan $2100 \mathrm{MHz}$.

\section{Menentukan Sel Planning}

\section{HASIL DAN PEMBAHASAN}

Proses sel planning, dapat menggambarkan semua kegiatan yang digunakan dalam proses perencanaan komunikasi radio dan mengkonfigurasikan sehingga sesuai dengan kondisi yang ada di lapangan. Sel planning dimulai dari menganalisis trafik dan daerah cakupan yang diinginkan sesuai dengan kondisi geografis serta jumlah yang dibutuhkan untuk mengcover pelanggan.

Jumlah pelanggan merupakan awal dalam merencanakan banyaknya jumlah eNode B yang akan ditempatkan. Jumlah pelanggan merupakan hal mendasar untuk menentukan banyaknya kanal frekuensi radio yang dibutuhkan. Data yang digunakan dalam menentukan jumlah pelanggan menggunakan provider Telkomsel 4G pada Bulan Agustus Tahun 2015 dengan jumlah pelanggan 800.000 pelanggan di seluruh Indonesia dengan jumlah pemakai $63 \%$ di wilayah DKI Jakarta[6], sehingga didapat pelanggan potensial sebanyak 504.000 jiwa.

Untuk menentukan besarnya trafik yang dibutuhkan pada mobile station perlu diketahui trafik untuk setiap pelanggan dan jumlah pelanggan. Di Indonesia saat ini besarnya trafik yang ditetapkan untuk setiap pelanggan adalah A= 11 mErlang, dengan standart Grade Of Service (GOS) yang disesuaikan yaitu sebesar 2\%[7]. Penentuan daerah layanan dimaksudkan agar perencanaan yang dilakukan difokuskan pada data yang berkaitan dengan daerah tersebut. Perencanaan penempatan eNode B ini dilakukan di daerah DKI Jakarta. DKI Jakarta terletak diantara $5^{\circ} 19^{\prime} 12^{\prime \prime}-6^{\circ} 23^{\prime} 54^{\prime \prime}$ LS hingga $106^{\circ} 22^{\prime} 42^{\prime \prime}-106^{\circ} 58^{\prime} 18^{\prime \prime}$ BT dengan luas wilayah daratan $661,52 \mathrm{~km}^{2}$. Diagram alir sel planning dapat dilihat pada Gambar 5. 


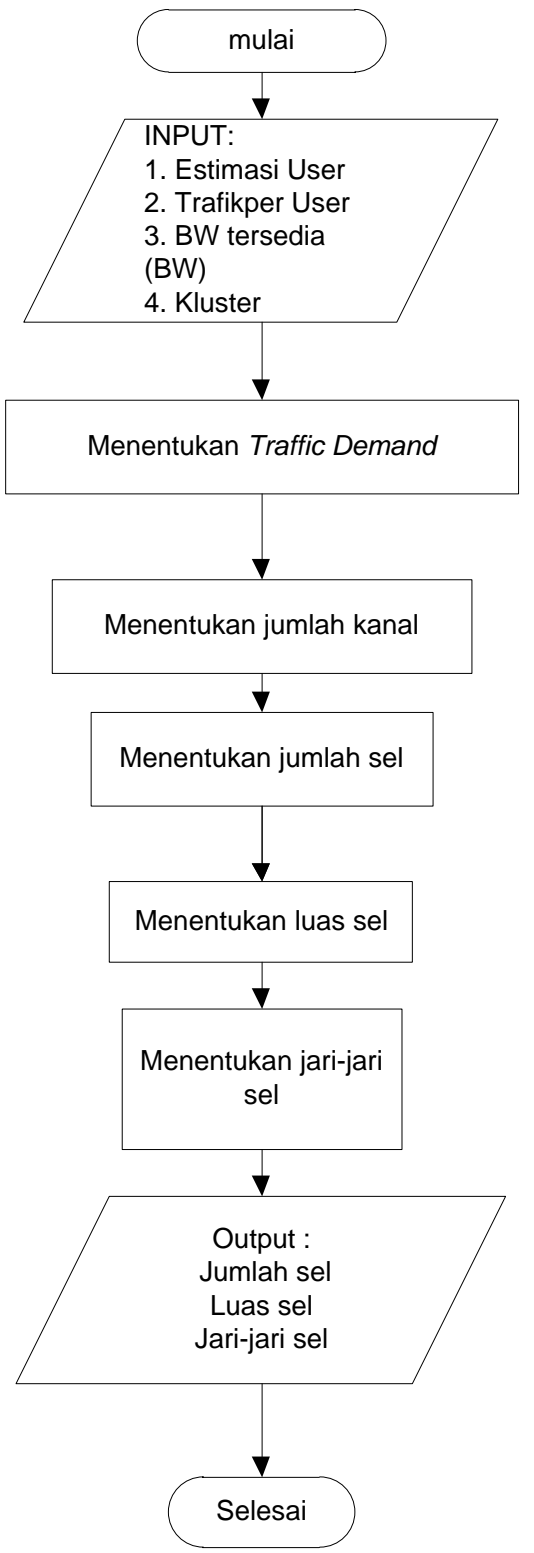

- Gambar 5. Diagram Alir Sel Planning

Berikut perhitungan sel planning :

a. Traffic Demand

A = Jumlah Pelanggan $\mathrm{x}$ Traffic rata-rata per user

$=504.000 \times 0,011$

$=5544$ Erlang

b. Jumlah Kanal

$\mathrm{N}=\mathrm{BW} / 200 \mathrm{KHz} \times 8 /$ kluster

$\mathrm{N}=20 \mathrm{MHz} / 200 \mathrm{KHz} \times 8 / 4$

$\mathrm{N}=200$ kanal

c. Jumlah Sel

Jumlah sel = traffic demand / Asel

Jumlah sel $=5544 / 62,95$

Jumlah sel $=88,07=88 \mathrm{sel}$

d. Luas Sel

Luas Sel $=$ Luas daerah $/$ jumlah sel

Luas Sel $=661,52 / 88$

Luas Sel $=7,52 \mathrm{Km}^{2}$

e. Jari-Jari Sel ( $\left.\mathrm{R}_{\text {sel }}\right)$

$\mathrm{R}_{\text {sel }}=(\text { Luas sel } / 2,6)^{1 / 2}$

Luas sel $=(7,52 / 2,6)^{1 / 2}$

Luas sel $=1,7 \mathrm{Km}$ 


\section{Menentukan Power Link Budget}

Perhitungan link budget merupakan perhitungan level daya yang dilakukan untuk memastikan bahwa level daya penerimaan lebih besar atau sama dengan level daya threshold. Tujuannya untuk menjaga keseimbangan gain dan loss guna mencapai Signal to Noise Ratio (SNR) yang diinginkan di receiver. Frekuensi yang akan digunakan dalam perencanaan ini adalah $1200 \mathrm{MHz}, 1800 \mathrm{MHz}, 2100 \mathrm{MHz}$ dan $2300 \mathrm{MHz}$. Pemilihan bandwidth $20 \mathrm{MHz}$ karena bandwidth $20 \mathrm{MHz}$ merupakan bandwidth maksimum yang ditetapkan oleh 3GPP. Jarak bangunan dominan dari tengah sel $10 \mathrm{~m}$ serta tinggi MS $\left(\mathrm{H}_{\mathrm{rx}}\right) \quad 1,7 \mathrm{~m}$ dengan jenis daerah urban.

Berikut perhitungan Power Link Budget :

a. Zona Fresnel (F)

$$
\begin{aligned}
& \mathrm{F}=17,3\left(\mathrm{~d} 1(\mathrm{D}-\mathrm{d} 1) / \mathrm{f}_{\mathrm{Ghz}} \mathrm{D}_{\mathrm{Km}}\right)^{1 / 2} \\
& \mathrm{~F}=1,566 \mathrm{~m}
\end{aligned}
$$

b. Clearance $(\mathrm{C})=0,6 \times \mathrm{F}$

$$
\begin{aligned}
& =0,6 \times 1,566 \\
& =0,9396 \mathrm{~m}
\end{aligned}
$$

c. HTX bangunan $=\mathrm{HrX}+\left\{\mathrm{C}+\left(\mathrm{h}\right.\right.$ bangunan $\left.\left.-\mathrm{h}_{\mathrm{rx}}\right)\right\} / \mathrm{D}(\mathrm{D}-\mathrm{d} 1)$

HTX bangunan $=21,2657 \mathrm{~m}$

d. Tinggi antena berdasarkan area akses $\left(\mathrm{H}_{\mathrm{tx}}\right)=42$

Bentuk digram alir power link budget dapat lihat pada Gambar 6.

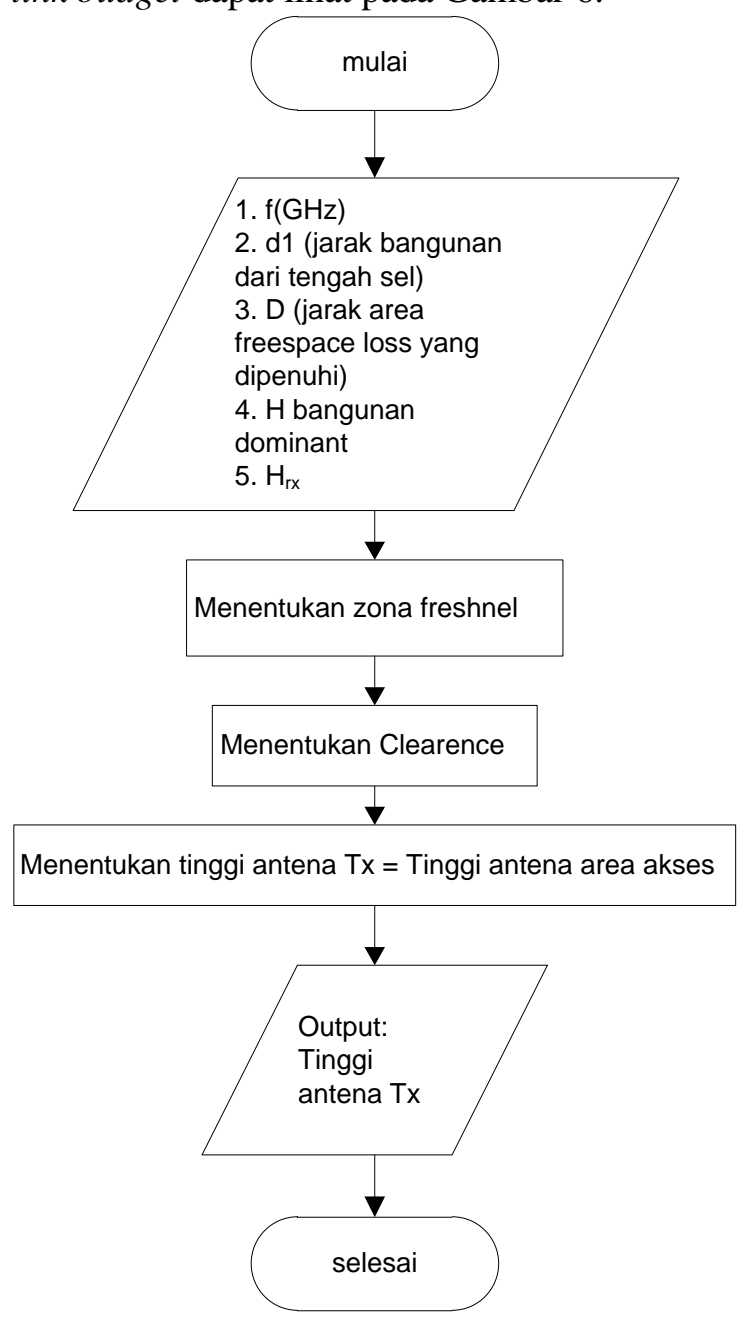

- Gambar 6. Diagram Alir Power Link Budget

\section{Menentukan Path Loss Model Okumura Hata dan Fading Margin}

Path Loss adalah loss yang terjadi ketika data/sinyal melewati media udara dari antena ke penerima dalam jarak tertentu. Path loss mengakibatkan penurunan level daya pada sisi penerima yang secara umum diakibatkan dengan adanya difraksi, refleksi, dan scattering. Bentuk digram alir Path Loss Okumura Hata dapat lihat pada Gambar 7. 


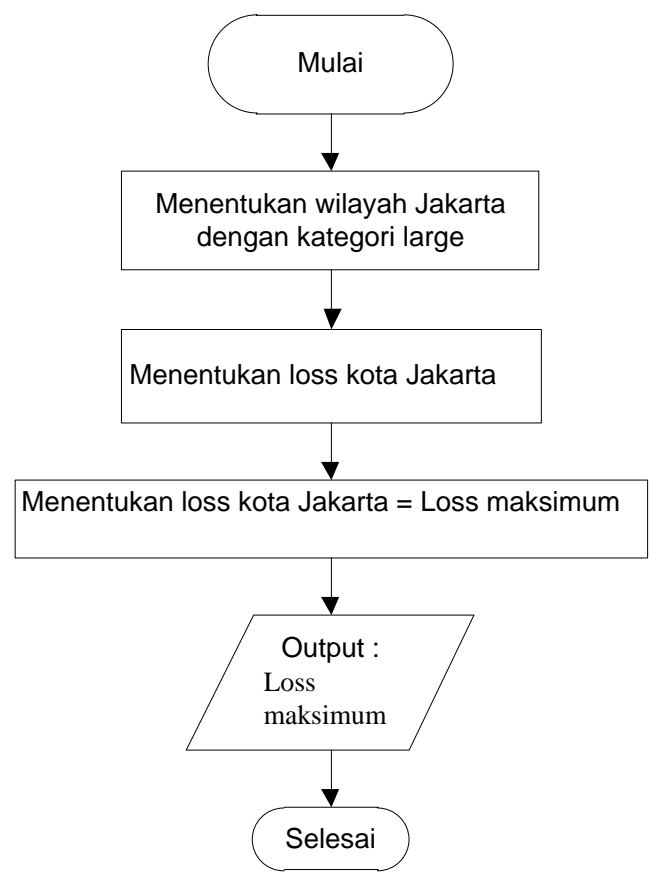

- Gambar 7. Diagram Alir Path Loss Okumura Hata

Berikut perhitungan path loss Okumura Hata :

a. $\mathrm{a}\left(\mathrm{hr}_{\mathrm{x}}\right)=3,2\left(\log 11,75 \mathrm{~h}_{\mathrm{rx}}\right)^{2}-1,1 \mathrm{~dB}$

$$
=9,49 \mathrm{~dB}
$$

b. L $_{\text {PROP CITY }}=69,55+26,16 \log \mathrm{f}-13,83 \log \mathrm{h}_{\mathrm{tx}}-\mathrm{a}\left(\mathrm{H}_{\mathrm{rx}}\right)+(44,9-6,55 \log$

$$
\begin{aligned}
& \left.=h_{\text {tx }}\right) \log r_{\text {sel }} \\
& =69,55+80,55-18,362-9,49+8,342 \\
& =130,59 \mathrm{~dB}
\end{aligned}
$$

c. Lprop $\max =$ LPROP CITY

$$
=130,59 \mathrm{~dB} \text { untuk daerah urban }
$$

Bentuk digram alir Fading Margin dapat lihat pada Gambar 8.

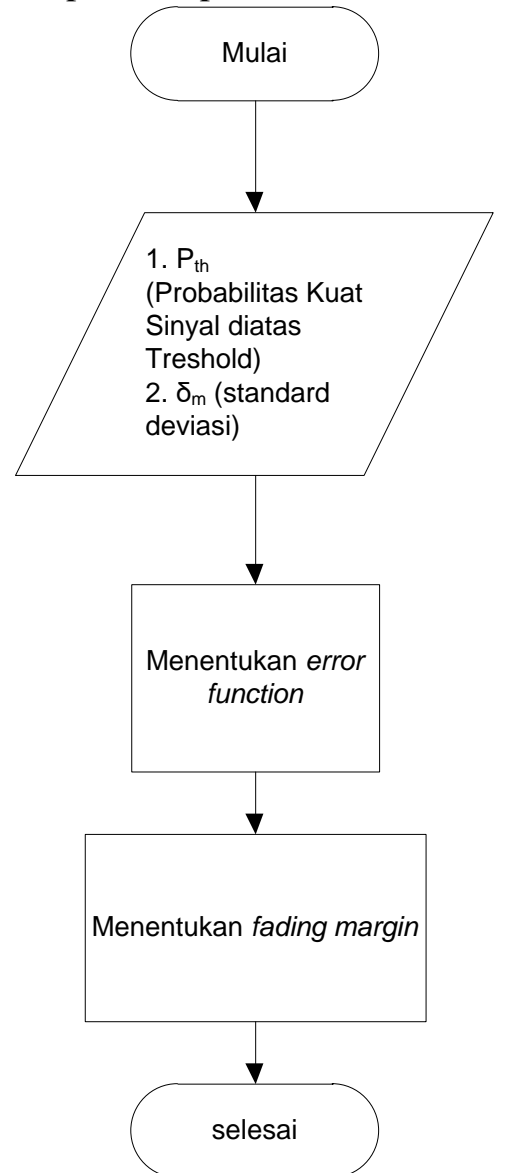

- Gambar 8. Diagram Alir Fading Margin 
Berikut perhitungan Fading Margin

a. Probabilitas kuat sinyal diatas threshold (Pth) : 0,8

b. Standarisasi : $8 \mathrm{~dB}$

c. Error function (erf)

$$
\begin{aligned}
\text { erf } & =(\text { Pth }-0,5) / 0,5=0,6 \\
\text { erf }^{-1} & =1 / 0,6 \\
& =1,67
\end{aligned}
$$

d. Fading Margin (FM)

$$
\begin{aligned}
\text { FM } & =\left(- \text { erf }^{-1}\right) \cdot \text { standarisasi }(2)^{1 / 2} \\
& =-1,67 \cdot 8 \cdot 1,41 \\
& =18,84 \mathrm{~dB}
\end{aligned}
$$

e. Rsel $=10$ (LPROP CITY $-69,55-26,16 \log \mathrm{fc}+13,8 \log \mathrm{htx}+\mathrm{a}(\mathrm{hrx}) / 44,9-6,55 \log \mathrm{htx}$

$$
\begin{aligned}
& =10^{(0,2293)} \\
& =1,6955 \mathrm{Km}
\end{aligned}
$$

\section{Spesifikasi Antena Uplink dan Downlink pada LTE 4G}

Daya yang dipancarkan oleh eNode B harus lebih besar dari perhitungan daya pancar eNode B yang telah seimbang dengan sistem, karena daya pancar eNode B lebih kecil dari perhitungan daya pancar eNode B yang telah seimbang dengan sistem. Maka perlu diadakan rekonfigurasi. Berikut dibawah ini Tabel 2 dan Tabel 3. spesifikasi Uplink dan Downlink antena eNode B.

- Tabel 2. Spesifikasi Uplink antena eNode B [4]

\begin{tabular}{|l|c|}
\hline \multicolumn{1}{|c|}{ Parameter } & Nilai \\
\hline Antena Gain & $33 \mathrm{~dB}$ \\
\hline Tx Power & $100 \mathrm{dBm}$ \\
\hline Cable Loss & $0 \mathrm{~dB}$ \\
\hline Rx Noise Figure & $2 \mathrm{~dB}$ \\
\hline E.I.R.P. & $2 \mathrm{dBm}$ \\
\hline Receveir Noise & $104 \mathrm{~dB}$ \\
\hline SIR & $18 \mathrm{~dB}$ \\
\hline Rx Antena Gain & $33 \mathrm{~dB}$ \\
\hline Fade Margin & $0 \mathrm{~dB}$ \\
\hline Interference Margin & $6 \mathrm{~dB}$ \\
\hline Body Loss & $0 \mathrm{~dB}$ \\
\hline
\end{tabular}

- Tabel 3. Spesifikasi Downlink antena eNode B [4]

\begin{tabular}{|l|c|}
\hline \multicolumn{1}{|c|}{ Parameter } & Nilai \\
\hline Antena Gain & $33 \mathrm{~dB}$ \\
\hline Tx Power & $100 \mathrm{dBm}$ \\
\hline Cable Loss & $0 \mathrm{~dB}$ \\
\hline Rx Noise Figure & $2 \mathrm{~dB}$ \\
\hline E.I.R.P. & $2 \mathrm{dBm}$ \\
\hline Receveir Noise & $104 \mathrm{~dB}$ \\
\hline SNR & $18 \mathrm{~dB}$ \\
\hline Rx Antena Gain & $5 \mathrm{~dB}$ \\
\hline Fade Margin & $0 \mathrm{~dB}$ \\
\hline Interference Margin & $6 \mathrm{~dB}$ \\
\hline Body Loss & $1 \mathrm{~dB}$ \\
\hline
\end{tabular}




\section{Algoritma Genetika Pada Penempatan eNode B Pengkodean}

Nilai jari-jari sel menggunakan variable frekuensi. Nilai range frekuensi yaitu $1200 \mathrm{MHz}, 1800 \mathrm{MHz}, 2100$ $\mathrm{MHz}$ dan $2300 \mathrm{MHz}$ sehingga nilai frekuensi menggunakan bilangan real dimulai dengan nilai frekuensi yang terkecil $1200 \mathrm{MHz}$ hingga frekuensi $2300 \mathrm{MHz}$. Pengkoden nilai frekuensi dapat ditunjukkan pada Tabel 4.

Tabel 4. Nilai Frekuensi

\begin{tabular}{|c|c|c|}
\hline No & Nilai Frekuensi (MHz) & Individu ( Bilangan Real) \\
\hline 1 & 1200 & $1200 \mathrm{MHz}$ \\
\hline 2 & 1800 & $1800 \mathrm{MHz}$ \\
\hline 3 & 2100 & $2100 \mathrm{MHz}$ \\
\hline 4 & 2300 & $2300 \mathrm{MHz}$ \\
\hline
\end{tabular}

\section{Nilai Fitness}

Nilai fitness berdasarkan parameter sel planning, power link budget, patt loss Okumura Hata hingga akhirnya didapatkan nilai fitness. Fitness yang didapatkan akan mendapatkan nilai jari-jari sel (Rsel). Dengan demikian untuk mendapatkan nilai fitness ini menggunakan persamaan :

Keterangan :

$$
\text { Nilai fitness }=10^{(\text {LPROP CITY }-69,55-26,16 \log \mathrm{f}+13,8 \log \mathrm{htx}+\mathrm{a}(\mathrm{hrx}) / 44,9-6,55 \log \mathrm{htx}}
$$

$$
\begin{aligned}
& \text { LPROP CITY = Loss maksimum }(\mathrm{dB}) \\
& \mathrm{f} \quad \quad=\text { Frekuensi }(\mathrm{MHz}) \\
& \text { htx } \quad=\text { Tinggi antena tx (m) } \\
& \mathrm{a}(\mathrm{hrx}) \quad=\text { Penguatan path loss }(\mathrm{dB})
\end{aligned}
$$

\section{Inisialisasi Populasi}

Inisialisasi populasi bertujuan untuk membangkitkan populasi yang berisi sejumlah kromosom. Setiap kromosom berisi jumlah gen. Masukan untuk fungsi ini adalah jumlah kromosom dan jumlah gen Sesuai dengan hasil perhitungan maka untuk populasi awal yang dibangkitkan adalah 1,6955 Kilometer (Km) hingga 1,6972 Kilometer $(\mathrm{Km})$. Populasi awal dari variable frekuensi dapat ditunjukkan pada Tabel 5.

- Tabel 5. Populasi awal dari Variable Frekuensi

\begin{tabular}{|c|c|c|}
\hline No & Individu (Nilai Frekuensi (MHz) & Jari-jari Sel (Rsel) \\
\hline 1 & 1200 & $1,6955 \mathrm{Km}$ \\
\hline 2 & 1800 & $1,6958 \mathrm{Km}$ \\
\hline 3 & 2100 & $1,6962 \mathrm{Km}$ \\
\hline 4 & 2300 & $1,6972 \mathrm{Km}$ \\
\hline
\end{tabular}

\section{Seleksi}

Metode seleksi yang digunakan dalam penelitian ini menggunakan roulette wheel (roda roulette) dan ini merupakan metode yang umum digunakan. Seleksi dengan roulette wheel memilih anggota populasi tertentu untuk menjadi orang tua dengan probabilitas sama dengan fitness dibagi dengan total fitness populasi. Pada seleksi ini, orang tua dipilih berdasarkan fitness mereka. Lebih baik suatu individu, lebih besar kesempatan terpilih. Probabilitas suatu individu terpilih untuk perkawinan silang sebanding dengan fitnessnya. Kromosom yang menempati nilai fitness terbesar menempati potongan lingkaran yang lebih besar dengan kromosom yang mempunyai nilai fitness rendah. Ranking nilai fitness individu dapat ditunjukkan pada Tabel 6 dibawah ini.

Tabel 6. Ranking Nilai Fitness Individu

\begin{tabular}{|c|c|c|}
\hline No & Individu (Nilai Frekuensi (MHz) & Fitness \\
\hline 1 & 1200 & $3,900 \mathrm{Km}$ \\
\hline 2 & 1800 & $3,9331 \mathrm{Km}$ \\
\hline 3 & 2100 & $3,9441 \mathrm{Km}$ \\
\hline 4 & 2300 & $3,9503 \mathrm{Km}$ \\
\hline
\end{tabular}


Untuk melakukan proses seleksi dengan roulette wheel, melalui beberapa tahapan berikut ini.

1. Menghitung nilai fitness dari masing-masing individu. Rumus fitness telah dirumuskan pada persamaan nilai fitness.

2. Menghitung nilai total fitness dari semua jari-jari sel.

Total Fitness $=3,900+3,9331+3,9441+3,9503=15,7275$

Jadi total nilai fitnessnya adalah 15,7275

3. Menghitung probabilitas masing-masing individu.

Nilai probabilitas individu dapat dilihat pada Tabel 7.

- Tabel 7. Nilai Probabilitas Individu

\begin{tabular}{|c|c|c|c|}
\hline No & $\begin{array}{c}\text { Individu } \\
\text { (Frekuensi) }\end{array}$ & $\begin{array}{c}\text { Fitness } \\
\text { (Rsel) }\end{array}$ & $\begin{array}{c}\text { Nilai } \\
\text { Probabilitas }\end{array}$ \\
\hline 1 & $1200 \mathrm{MHz}$ & $3,900 \mathrm{Km}$ & 0,248 \\
\hline 2 & $1800 \mathrm{MHz}$ & $3,9331 \mathrm{Km}$ & 0,25 \\
\hline 3 & $2100 \mathrm{MHz}$ & $3,9441 \mathrm{Km}$ & 0,251 \\
\hline 4 & $2300 \mathrm{MHz}$ & $3,9503 \mathrm{Km}$ & 0,2512 \\
\hline & Total & 15,7275 & \\
\hline
\end{tabular}

4. Menghitung jatah masing-masing individu antara 1- 100.

Dari ke 4 individu diurutkan untuk diberi jatah dari 1 sampai 100. Untuk individu yang pertama diberikan nilai 1 sampai dengan nilai probabilitasnya. Jatah untuk setiap individu dapat ditunjukkan pata Tabel 8. Gambar 9 menunjukkan presentasi fitness.

Tabel 8. Jatah Setiap Individu

\begin{tabular}{|c|c|c|c|c|c|}
\hline No & Individu (Frekuensi) & Fitness (Rsel) & Nilai Probabilitas & Persentase & Jatah \\
\hline 1 & $1200 \mathrm{MHz}$ & $3,900 \mathrm{Km}$ & 0,248 & 24,8 & $1-24,8$ \\
\hline 2 & $1800 \mathrm{MHz}$ & $3,9331 \mathrm{Km}$ & 0,25 & 25 & $24,9-49,8$ \\
\hline 3 & $2100 \mathrm{MHz}$ & $3,9441 \mathrm{Km}$ & 0,251 & 25,1 & $49,9-74,9$ \\
\hline 4 & $2300 \mathrm{MHz}$ & $3,9503 \mathrm{Km}$ & 0,2512 & 25,12 & $75-100$ \\
\hline & Total & 157,275 & 1 & & \\
\hline
\end{tabular}

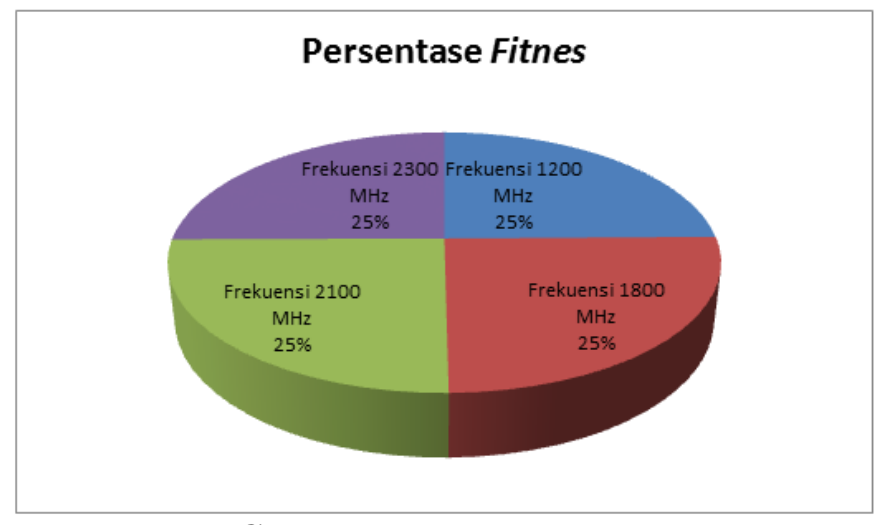

- Gambar 9. Persentase Fitnes

Berdasarkan hasil nilai fitness pada penempatan eNode B dengan menggunakan algoritma genetika bahwa frekuensi $2300 \mathrm{MHz}$ memiliki jari-jari sel yang lebih baik.

\section{Evolutionary Programming Pada Penempatan eNode B Pengkodean}

Nilai jari-jari sel menggunakan variable frekuensi. Nilai range frekuensi yaitu $1200 \mathrm{MHz}, 1800 \mathrm{MHz}, 2100$ $\mathrm{MHz}$ dan $2300 \mathrm{MHz}$ sehingga nilai frekuensi menggunakan bilangan real dimulai dengan nilai frekuensi yang terkecil $1200 \mathrm{MHz}$ hingga frekuensi $2300 \mathrm{MHz}$. Pengkoden nilai frekuensi dapat ditunjukkan pada Tabel 9. 
Tabel 9. Nilai Frekuensi

\begin{tabular}{|c|c|c|}
\hline No & Nilai Frekuensi (MHz) & Individu (Bilangan Real) \\
\hline 1 & 1200 & $1200 \mathrm{MHz}$ \\
\hline 2 & 1800 & $1800 \mathrm{MHz}$ \\
\hline 3 & 2100 & $2100 \mathrm{MHz}$ \\
\hline 4 & 2300 & $2300 \mathrm{MHz}$ \\
\hline
\end{tabular}

\section{Nilai Fitness}

Nilai fitness berdasarkan parameter sell planning, power link budget, patt loss Okumura Hata hingga akhirnya didapatkan nilai fitness. Fitness yang didapatkan akan mendapatkan nilai jari-jari sel (Rsel). Dengan demikian untuk mendapatkan nilai fitness ini menggunakan persamaan :

Nilai fitness $=10^{(\text {LPROP CITY }-69,55-26,16 \log \mathrm{fc}+13,8 \log \mathrm{htx}+\mathrm{a}(\mathrm{hrx}) / 44,9-6,55 \log \mathrm{htx}}$

Keterangan :

$\mathrm{L}_{\mathrm{PROP} \text { CITY }} \quad=$ Loss maksimum $(\mathrm{dB})$

$\mathrm{f} \quad \quad=$ Frekuensi $(\mathrm{MHz})$

htx $\quad=$ Tinggi antena tx $(\mathrm{m})$

$\mathrm{a}(\mathrm{hrx}) \quad=$ Penguatan path loss $(\mathrm{dB})$

\section{Inisialisasi Populasi}

Inisialisasi populasi bertujuan untuk membangkitkan populasi yang berisi sejumlah kromosom. Setiap kromosom berisi jumlah gen. Masukan untuk fungsi ini adalah jumlah kromosom dan jumlah gen Sesuai dengan hasil perhitungan maka untuk populasi awal yang dibangkitkan adalah 1,6955 Kilometer (Km) hingga 1,6972 Kilometer (Km). Populasi awal dari variable frekuensi dapat ditunjukkan pada Tabel 10.

Tabel 10. Populasi awal dari Variable Frekuensi

\begin{tabular}{|c|c|c|}
\hline No & Individu (Nilai Frekuensi (MHz) & Jari-jari Sel (Rsel) \\
\hline 1 & 1200 & $1,6955 \mathrm{Km}$ \\
\hline 2 & 1800 & $1,6958 \mathrm{Km}$ \\
\hline 3 & 2100 & $1,6962 \mathrm{Km}$ \\
\hline 4 & 2300 & $1,6972 \mathrm{Km}$ \\
\hline
\end{tabular}

\section{Seleksi}

Seleksi merupakan bagian yang penting dalam menentukan nilai fitness function. Fitness function merupakan komponen yang krusial dalam suatu evolutionary programming. Fitness function berperan untuk menentukan individual mana yang akan bereproduksi dan sebagian materi genetiknya akan diwariskan kepada penerusnya/generasi berikutnya. Ranking nilai fitness individu dapat ditunjukkan pada Tabel 11 dibawah ini.

Tabel 11. Ranking Nilai Fitness

\begin{tabular}{|c|c|c|c|c|c|}
\hline No & Individu (Frekuensi) & Fitness (Rsel) & Nilai Probabilitas & Persentase & Jatah \\
\hline 1 & $1200 \mathrm{MHz}$ & $3,900 \mathrm{Km}$ & 0,248 & 24,8 & $1-24,8$ \\
\hline 2 & $1800 \mathrm{MHz}$ & $3,9331 \mathrm{Km}$ & 0,25 & 25 & $24,9-49,8$ \\
\hline 3 & $2100 \mathrm{MHz}$ & $3,9441 \mathrm{Km}$ & 0,251 & 25,1 & $49,9-74,9$ \\
\hline 4 & $2300 \mathrm{MHz}$ & $3,9503 \mathrm{Km}$ & 0,2512 & 25,12 & $75-100$ \\
\hline & Total & 157,275 & 1 & & \\
\hline
\end{tabular}

Berdasarkan hasil nilai fitness pada penempatan eNode B dengan menggunakan evolutionary programming bahwa frekuensi $2300 \mathrm{MHz}$ memiliki jari-jari sel yang lebih baik. 


\section{KESIMPULAN}

Penempatan eNode B menggunakan algoritma genetika dan evolutionary programming memiliki nilai yang sama dalam menentukan demand trafik dan daya jangkauan di kota DKI Jakarta. Dalam menentukan daerah yang tercover diwilayah DKI Jakarta dengan menggunakan algoritma genetika dan evolutionary programming sama baiknya hal ini dibuktikan dengan mendapatkan nilai jari-jari sel yang sama. Hasil penempatan jumlah eNode B dengan menggunakan frekuensi $2300 \mathrm{MHz}$ lebih efisien karena memiliki nilai jari-jari yang lebih besar jika dibandingkan dengan frekuensi $1200 \mathrm{MHz}, 1800 \mathrm{MHz}$ dan $2100 \mathrm{MHz}$.

\section{DAFTAR ACUAN}

[1] M. F. Hakim, W. Anggraeni, dan A. Pribadi, Optimasi Perencanaan Jumlah Base Transceiver Station (BTS) dan Kapasitas Trafik BTS Menggunakan Pendekatan Goal Programming Pada Sistem Telekomunikasi Seluler Berbasis GSM, Jurnal Teknik ITS, Vol 1 (September 2012).

[2] S. Ariyanti, Studi Perencanaan Jaringan Long Term Evolution Area Jabodetabek Studi Kasus PT. Telkomsel, Jakarta: Buletin dan Telekomunikasi, 2014.

[3] Suyanto, Algoritma Genetika dalam Matlab, Yogyakarta: Andi Yogyakarta, 2005.

[4] P. D. Aryanti, S. H. Pramono, dan O. Setyawati, Optimasi Penempatan Node B UMTS 900 Pada BTS Existing Menggunakan Algoritma Genetika, Jurnal EECCIS, Vol 7, No. 2 (Desember 2013).

[5] U. K. Usman, G. Prihatmoko, D.K. Hendraningrat, dan S. D. Purwanto, Fundamental Teknologi Seluler, Bandung, Rekayasa Sains. 2012.

[6] G. Kaonang, 2015. "Dari Target 3 Juta Pelanggan 4G/LTE Telkomsel Sudah Mencapai Angka 800 Ribu". DailySocial. 3 Agustus 2015.

[\#] G. Wibisono, U.K. Usman, dan G.D. Hantoro, Konsep Teknologi Seluler, Bandung, Informatika. 2008. 